\title{
Pemetaan Kedalaman Laut Menggunakan Multibeam Echosounder, (MB1) di Perairan Punggur, Kepri
}

\author{
Dodi Prima Resda ${ }^{1}$, Muhammad Zainuddin Lubis ${ }^{2}$, Dirgan Timbang ${ }^{3}$ \\ Politeknik Negeri Batam \\ Teknik Informatika \\ Jl. Ahmad Yani, Batam Centre, Batam 29461, Indonesia \\ dodi.prima@polibatam.ac.id, zainuddinlubis@polibatam.ac.id,dirgantimbang@gmail.com
}

\begin{abstract}
Abstrak
Penelitian ini dilakukan pada bulan April 2018 di perairan Punggur untuk melakukan penelitian ini dilakukan menggunakan metode survei batimetri dan pasut bertujuan mendapatkan informasi kedalaman dan posisi di perairan Punggur yang berperan untuk mendukung aktifitas di sekitar perairan Punggur. Penelitian ini dilakukan dengan melakukan pemeruman menggunakan intrumen Multibeam Echosounder (MBES) System. Pasang surut mengetahui dinamika atau perubahan permukaan laut dengan demikian maka di lakukan survei batimetri dan survei pasang surut secara bersamaan yaitu pasang surut pada kegiatan survei batimetri bertujuan sebagai bidang acuan kedalaman untuk menentukan jenis/tipe Pasut dan ketinggian muka air laut rata-rata MSL(Mean Sea Level) sebagai titik referensi (titik nol) untuk pengukuran elevasi. Nilai Formzahl diketahui nilai besaran bilangan Formzahl adalah 1,35 Sehingga tipe pasut pada Perairan sekitaran pelabuhan yaitu tipe campuran condong ganda (Mixed mainly diurnal tides). Hasil pengukuran batimetri yang telah di koreksi dengan nilai MSL 1,35 meter yang menghasilkan akurasi pada nilai kedalaman. Hal ini menunjukkan dengan adanya perubahan nilai kedalaman di perairan punggur, Batam. Hasil penelitian menunjukan nilai kedalaman di perairan punggur berkisar antara 16 sampai 25 meter di bawah permukaan laut, sehingga nilai kedalaman atau batimetri di perairan tersebut tidak termasuk berada di daerah continental shelf yang menjelaskan dengan adanya nilai topografi landai.
\end{abstract}

Kata kunci: Batimetri, Perairan Punggur, Pasang Surut, Multibeam Echosounder (MBES)

\begin{abstract}
This research was conducted in April 2018 at Punggur waters. The methods used were bathymetric and tidal survey which aimed at obtaining depth and position information in Punggur waters which play a role in supporting activities around Punggur waters. This research was done by performing generalization using the Multibeam Echosounder (MBES) System instrument. Tides know the dynamics or changes in sea level. Thus, a bathymetric and tidal survey are carried out simultaneously namely the tides in the bathymetry survey activities aiming as a reference depth field to determine the kind/type of tide and the height of sea level average MSL (Mean Sea Level) as a reference point (zero points) for elevation measurements. It is known that the Formzahl value is 1.35 so that the tide type in the waters around the port is mixed mainly diurnal tides. The corrected bathymetry measurement results with an MSL value of 1.35 meters which results in an accuracy of the depth value. This indicates that there is a change in the depth value in Punggur waters, Batam. The results showed that the depth value in Punggur waters ranged from 16 to 25 meters below sea level so that the depth or bathymetry value in these waters was not included in the continental shelf area, which explains the presence of sloping topography values.
\end{abstract}

Keywords: Bathymetry, Punggur waters, tides, Multibeam Echosounder (MBES) 


\section{Pendahuluan}

Perairan Punggur merupakan perairan dangkal yang di kelilingi banyak pulau-pulau kecil. Perairan Punggur masih sangat membutuhkan penelitian unggul, terutama dibidang pemetaan dasar laut, baik kedalaman, dan fitur dasar laut menggunakan teknik Hidrografi dan Akustik. Hal ini sangat membutuhkan adanya penelitian dengan menggunakan alat akustik dalam survei hidrografi yaitu Multibeam Echosounder (MBES). Survei batimetri adalah suatu kegiatan pengukuran kedalaman laut dan pengukuran dasar perairan untuk mendapatkan suatu informasi sebuah bentuk topografi di dasar perairan. Data batimetri di perairan laut Punggur memiliki nilai perbedaan dalam pengukuran kedalaman 16-26 meter dengan perbedaan metode kedalaman koordinat untuk mendapatkan sebuah perbandingan nilai grafik kedalaman. Dalam survei batimetri pengukuran kedalaman laut dengan menggunakan Multibeam Echosounder (MBES) Teledyne odom dapat menghasilkan gambaran topografi dasar laut secara jelas yang dibandingkan untuk mendapatkan nilai perbedaan pada kedalaman laut Punggur Batam. Survei batimetri juga membutuhkan pengukuran pasang surut di dermaga Punggur untuk melihat kondisi fisik laut Punggur dan menjadi parameter sebuah kondisi fisik laut di pulau Batam. Data pasang surut perairan Punggur pada 7 April 2018 kecepatan arus $0,05 \mathrm{~m} / \mathrm{det}-0,90 \mathrm{~m} / \mathrm{det}$ dengan kecepatan arus lebih besar surut di bandingkan kecepatan pasang begitu juga dengan pola arus lebih arah timur.

Penelitian terdahulu melakukan penelitian dengan judul "Pembuatan Program Penentuan Konstanta Harmonik dan Prediksi Data Pasang Surut dengan Menggunakan Visual Basic For Application (Vba) Ms. Excel"[1]. Penelitian ini mengumpulkan data pasang surut laut yang diperlukan pengukuran dan pengolahan data pasut guna mendapatkan nilai Muka Air Laut Rerata untuk membantu pengukuran dalam survei batimetri. Selain itu juga proses pengukuran pasang surut akan menghasilkan komponen konstanta harmonik, dimana komponen tersebut berguna untuk memprediksi pasang surut yang akan terjadi dikemudian hari. Selain itu juga proses pengukuran pasang surut akan menghasilkan komponen konstanta harmonik, dimana komponen tersebut berguna untuk memprediksi pasang surut yang akan terjadi dikemudian hari.

\section{Metode Penelitian}

\subsection{Lokasi Penelitian}

Lokasi penelitian dilakukan di daerah Pulau Batam, di Perairan Punggur awal melakukan survei pada koordinat $01^{\circ} \quad 02$ ' 01,70 'LU $104^{\circ} \quad 08^{\prime} 26,77^{\prime \prime} \mathrm{BT}$ sampai dengan survei akhir pada koordinat $01^{\circ} 02^{\prime}$ 03,38'LU $104^{\circ}$ 08'26,04'BT wilayah Perairan Punggur sangat berpengaruh terhadap aktifitas di sekitar perairan dengan adanya gambaraan atau informasi berbentuk peta dapat membantu aktifitas di sekitar Perairan Punggur.penelitian dapat dilihat pada Gambar 1.

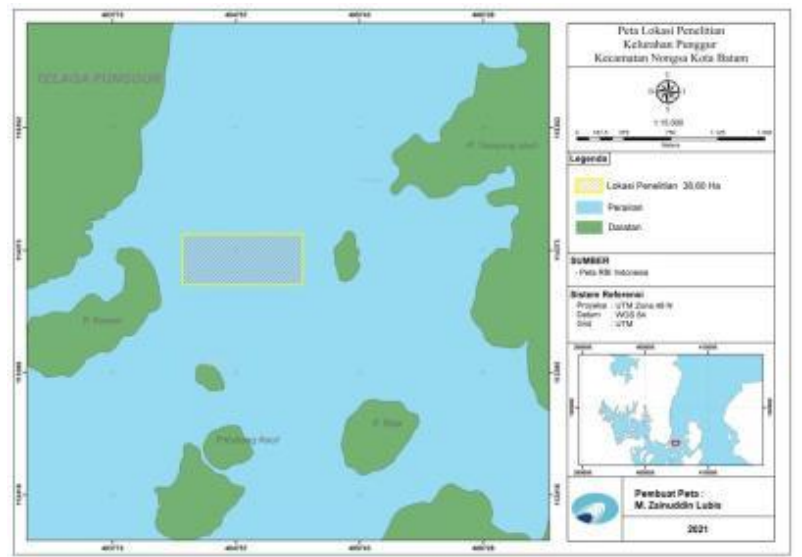

Gambar 1. Lokasi Penelitian 


\subsection{Desain Penelitian}

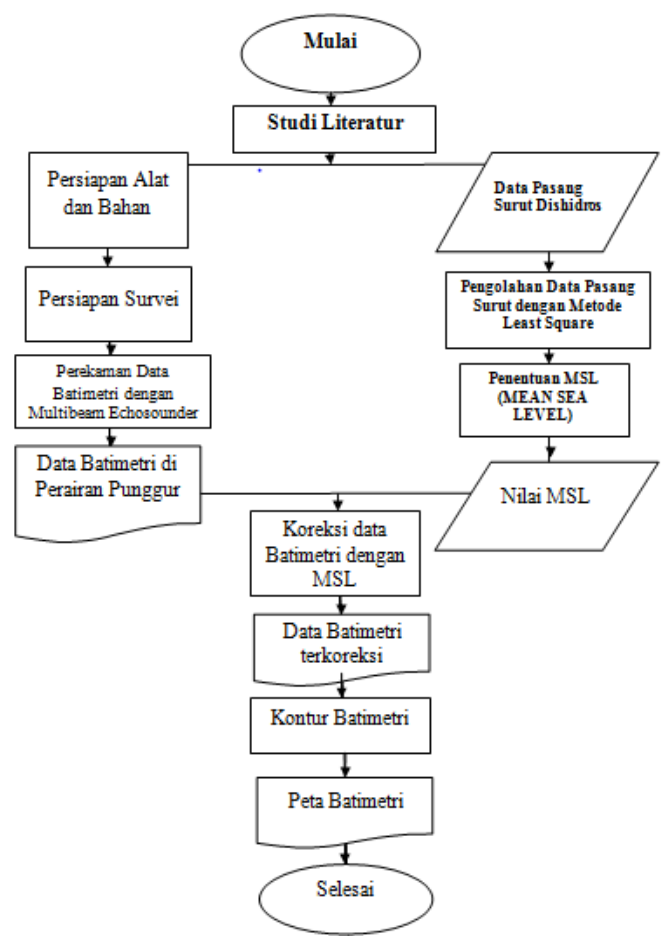

Gambar 2. Diagram Alir Penelitian

\subsection{Alat dan Bahan Penelitian}

Alat yang digunakan adalah Multibeam Echosounder Odom teledyne (MB1) pengambilan data multibeam pada 7 april 2018 di Perairan Punggur, Batam, Kepulauan Riau. Data pasang surut, bersumber dari Buku Dishidros TNI ANGKATAN LAUT, data pasang surut yang di gunakan 15 hari pada tanggal 1 april 2018 sampai dengan tanggal 15 april 2018. Data kedalaman perairan Punggur Kecamatan Nongsa yang di ambil secara langsung, waktu pengambilan data pada tanggal 7 April 2018, proses pengambilan data menggunakan alat Multibeam Echosounder Odom teledyne(MB1). Data Sekunder Citra lokasi, untuk membuat desain alur survei sekaligus untuk melihat kondisi lapangan, Citra di peroleh dari google earth, berikut adalah Tabel 1. Alat dan Bahan:

Tabel 1. Alat dan Bahan Penelitian

\begin{tabular}{|c|l|}
\hline No. & \multicolumn{1}{|c|}{ Alat } \\
\hline 1. & $\begin{array}{l}\text { Multibeam Echosounder (MBES) } \\
\text { Teledyne odom MB1 }\end{array}$ \\
\hline 2. & Perahu nelayan \\
\hline 3. & Klem transduser \\
\hline
\end{tabular}

\begin{tabular}{|c|l|}
\hline 4. & Batang transduser \\
\hline 5. & $\begin{array}{l}\text { Kabel penghubung antara perekam dan } \\
\text { accu (1 set) }\end{array}$ \\
\hline 6. & $\begin{array}{l}\text { Receiver HEMISPHERE GPS map } \\
\text { Sounder } \\
\text { Antena receiver GPS map (2 buah ) }\end{array}$ \\
\hline 7. & $\begin{array}{l}\text { Kabel dari receiver ke antena map (2 } \\
\text { buah) }\end{array}$ \\
\hline 8. & Barcheck (1 buah ) \\
\hline 9. & Accu (1 buah ) \\
\hline 10. & $\begin{array}{l}\text { GPS garmin navigasi (GPS Map 76) (1 } \\
\text { buah ) }\end{array}$ \\
\hline 11. & Genset (1 buah) \\
\hline 12. & Rambu ukur (2 buah) \\
\hline 13. & $\begin{array}{l}\text { Peralatan penunjang lainnya (1buah )tool } \\
\text { box }\end{array}$ \\
\hline 14. & Alat pencatat waktu 1 (1 buah) \\
\hline 15. & Roll meter 30 m (1 buah) \\
\hline 16. & Alat tulis (1 buah) \\
\hline 17. & Formulir pengukuran (5 buah) \\
\hline No. & \multicolumn{1}{c|}{ Bahan } \\
\hline 1. & Data Penentuan Posisi Kapal \\
\hline 2. & Data skunder pasang surut \\
\hline 3. & Data Penentuan Posisi Kapal \\
\hline 4. & $\begin{array}{l}\text { Data kedalaman hasil pengukuran } \\
\text { Multibeam } \\
\text { teledyne(MB1) }\end{array}$ \\
\hline
\end{tabular}

\subsection{Metode pengukuran batimetri}

Batimetri (bathimetry) dapat diartikan sebagai pengukuran dan pemetaan topografi dasar laut[4]. Adapun pengertian Survei batimetri adalah pengukuran kedalaman laut dilakukan untuk mendapatkan koordinat $\mathrm{x}, \mathrm{y}$, dan $\mathrm{z}$ pada masing-masing fix point. Koordinat $\mathrm{x}$ dan $\mathrm{y}$ didapatkan dengan menggunakan GPS, sedangkan kedalamannya (z) didapatkan dengan menggunakan MBES. Data kedalaman hasil dari perekaman akan di lakukan Koreksi terhadap pasang surut sebagai koreksi fenomena pasang surut terhadap pengukuran kedalaman. Ketinggian muka air laut yang berubah-ubah akan mempengaruhi kedudukan wahana yang digunakan selama pengukuran. Hal ini menyebabkan data pengukuran kedalaman laut terhadap wahana perlu diikatkan pada satu referensi yang tetap. Adapun kegiatan survei batimetri terlampir pada Meliputi beberapa tahapan yaitu:

1. Persiapan Alat dan Bahan 
Persiapan alat dan bahan merupakan tahap penetapan alat dan bahan yang akan dibutuhkan pada proses pengukuran. Persiapan meliputi pengumpulan data tahap awal, mobilisasi personil dan peralatan, pembuatan jalur pemeruman, pengecekan kelengkapan dan peralatan yang akan digunakan untuk pengambilan data, serta kalibrasi peralatan.

2. Pemasangan Alat Survei

Pemasangan alat di atas kapal harus dilakukan dengan sangat hati hati karena kondisi kapal yang tidak bisa diam di tempat maka proses ini sangat membutuhkan kehati-hatian dan juga sesuai dengan standar operasi.

\section{Navigasi}

Memastikan posisi tanduser terhadap kapal survei berada pada posisi sebenarnya untuk proses akuisisi gps kita menggunakan software Teledyne PDS software ini digunakan selain sebagai record data raw software ini juga sekaligus sebagai navigasi kapal pada saaat pelaksannaan survei.

\section{Kalibrasi alat}

Kalibrasi bacaan alat dilakukan dengan melakukan koreksi kecepatan gelombang suara menggunakan Barcheck yang terbuat dari lempengan logam berbentuk lingkaran atau segi empat yang digantungkan pada tali atau rantai berskala dan diletakkan dibawah transducer. Tali atau rantai berskala digunakan sebagai pembanding hasil ukuran dengan hasil yang terbaca oleh alat perum gema. Pembandingan pengukuran kedalaman dilakukan untuk setiap perubahan kedalaman, mulai dari 0 meter hingga kedalaman maksimum yang akan diperum dengan interval 1 meter [7] Fungsi lempeng logam ini adalah sebagai reflektor gelombang yang dipancarkan transducer.

\section{Jalur Pemeruman}

Jalur pemeruman dibuat tegak lurus dengan garis pantai untuk mendapatkan data kedalaman secara akurat[7]. Pembuatan lajur perum merupakan jalur perekaman data batimetri yang akan diikuti kapal dalam melintasi area survei. Lajur perum ini dibuat menjadi dua lajur, secara menyeluruh di area penelitian. Gambar 3, merupakan desain alur pemeruman pada saat melakukan survei batimetri dimana interval antar lajur pemeruman berjarak $25 \mathrm{~m}$.

Proses pemeruman dimulai dari line 1 sampai dengan line 2 dimana jarak keseluruhan berkisar 8 meter dengan luasan area pemeruman sekitar 500 meter yang menghasilkan 450 titik poin perekaman data pemeruman.

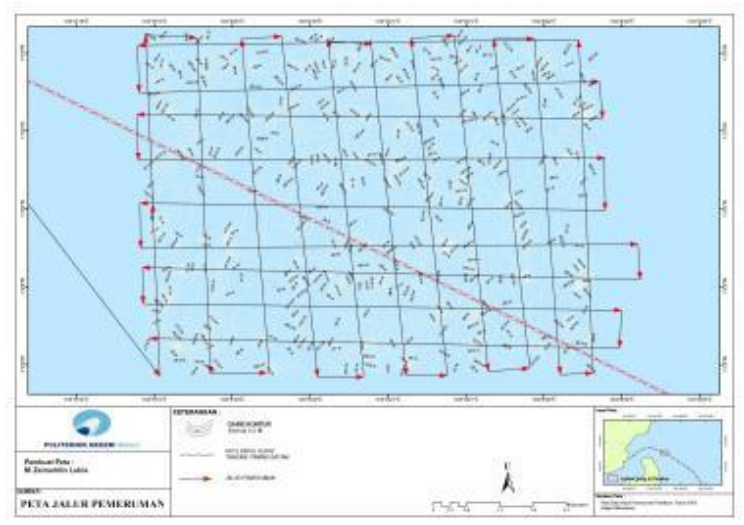

Gambar 3. Peta Jalur Pemeruman di laut Punggur Pulau Batam

Penggunaan alat ini merupakan pengukuran kedalaman secara tidak langsung dengan mengukur waktu tempuh pulsa gelombang akustik yang dipancarkan oleh transduser. Interval waktu tempuh gelombang akustik tersebut kemudian dikonversi menjadi kedalaman dengan prinsip sebagai berikut. Rumus dibawah merupakan fungsi kedalaman laut yang diukur:

$$
\mathrm{D}=\frac{1}{2}+(\mathrm{V} \cdot \Delta \mathrm{t})
$$

Keterangan:

$\mathrm{D}=$ Kedalaman $(\mathrm{m})$

$\mathrm{V}=$ Cepat rambat gelombang akustik dalam air $(\mathrm{m} / \mathrm{s})$ $\Delta \mathbf{t}=$ interval waktu antara gelombang yang dipancarkan dan diterima (s)

\section{Proses Pengolahan Data}

Gaya tarik gravitasi menarik air laut ke arah bulan dan matahari dan menghasilkan dua tonjolan (bulge) pasang surut gravitasional di laut. Lintang dari tonjolan pasang surut ditentukan oleh deklinasi, sudut antara sumbu rotasi bumi dan bidang orbital bulan dan 
matahari[7]. Pengolahan Data merupakan kegiatan yang dilakukan setelah kegiatan selesai dilakaukan dengsn menggunakan software pendukung yang dapat mempermudah kita dalam memahami hasil survei dan juga menghasilkan informasi yang bermanfaat, sesuai dengan yang direncanakan adapun proses pengolahannya sebagai berikut:

Proses Pengambilan data di Lapangan :

1. Menyiapkan alat-alat survey

2. Kemudian melakukan pengukuran lapangan untuk perekaman data batimetri

3. Kemudian pengumpulan data dan pengolahan untuk menjadi peta.

\section{- Metode pengolahan Pasang Surut}

Metode Least Square menggunakan perangkat lunak Ms.Excel, digunakan untuk menganalisis amplitudo dan fase setiap komponen harmonik pasang surut dari data pasang surut yang diolah. Dalam tipe pasang surut metode Least Square digunakan untuk menganalisis amplitudo dan fase setiap komponen harmonik pasang surut dari data pasang surut yang diolah dan Pasang Surut disajikan dalam bentuk Grafik.

\section{- $\quad$ Metode Pasang Surut Dengan Least Square}

MSL = Muka air laut rerata (mean sea level), adalah muka air rerata antara muka air tinggi rerata dan muka air rendah rerata. Elevasi ini digunakan sebagai referensi untuk elevasi di daratan.

HWS = Elevasi rata-rata muka air tertinggi (high water spring)

LWS = Muka air surutan terendah (low water spring)

Menentukan Chart datum (Z0) dalam penelitian ini dihitung menggunakan persamaan yang digunakan DISHIDROS Cilacap[6] sebagai berikut :

$$
\mathrm{Z} 0=\mathrm{S} 0-(1.2 \times(\mathrm{M} 2+\mathrm{S} 2+\mathrm{K} 2) .
$$

Keterangan :

S0 : Muka air rerata (Mean Sea Level)

Z0 : Chart Datum
M2 : Pasang surut semi diurnal yang dipengaruhi oleh bulan

S2 : Pasang surut semi diurnal yang dipengaruhi oleh matahari

K2 : Pasang surut semi diurnal karena pengaruh perubahan jarak akibat lintasan bulan yang elips.

Dalam menentukan tipe pasang surut yang terjadi di area dermaga bisa menggunakan rumus Bilangan Formzahl[3]yang dirumuskan: Bilangan Formzahl digunakan untuk mengetahui tipe pasang surut yang terjadi diperairan yang dirumuskan:

$$
\mathrm{F}=\frac{(\mathrm{AK} 1+\mathrm{AO} 1)}{(\mathrm{AM} 2+\mathrm{AS} 2)}
$$

\section{Keterangan:}

$\mathrm{F}=$ Formzahl

AK1 = Amplitudo anak gelombang pasang surut harian tunggal rata-rata dipengaruhi oleh deklinasi bulan dan matahari

AO1 = Amplitudo anak gelombang pasang surut harian tunggal dipengaruhi oleh deklinasi bulan

AM2 = Amplitudo anak gelombang pasang surut harian ganda rata-rata dipengaruhi oleh bulan

AS2 = Amplitudo anak gelombang pasang surut harian ganda rata-rata dipengaruhi oleh matahari

Nilai F berada antara [7]:

$\mathrm{F} \leq 0.25$ = Pasang surut harian ganda (semi diurnal tide)

$\mathrm{F} \geq 3.00=$ Pasang surut harian tunggal (diurnal tide)

$0.25<\mathrm{F}<1.50=$ Pasang surut campuran condong harian ganda

$1.50<\mathrm{F}<3.00=$ Pasang surut campuran condong harian tunggal 


\section{Hasil dan Pembahasan}

Data pasang surut diambil dari buku milik TNI Angkatan Laut yang dikeluarkan edisi terbaru tahun April 2018, data yang di gunakan 15 hari, 1 april 2018 sampai dengan 15 april 2018 . Berikut adalah tabel harmonik hasil analisa pasang surut.

Tabel 2. Hasil Harmonik 9 bilangan konstanta

\begin{tabular}{|c|c|c|c|c|c|c|c|}
\hline \multirow[t]{2}{*}{ No } & \multirow[t]{2}{*}{ Symbol } & \multicolumn{3}{|c|}{ Parameter } & \multirow{2}{*}{\begin{tabular}{c|} 
Aplitudo \\
meter
\end{tabular}} & \multirow{2}{*}{$\begin{array}{l}\text { Phase } \\
\text { der jam }\end{array}$} & \multirow{2}{*}{$\begin{array}{l}\text { Phase } \\
\text { radjam }\end{array}$} \\
\hline & & $\mathrm{zo}$ & $\mathrm{A}$ & B & & & \\
\hline 0 & zo & 1.8009 & & & 1.8009 & & \\
\hline 1 & $\mathrm{M} 2$ & & 0.5199 & 0.5588 & 0.7632 & 47.0664 & 0.8215 \\
\hline 2 & $\mathrm{~S} 2$ & & 0.7678 & -0.0085 & 0.7678 & 359.3676 & 6.2721 \\
\hline 3 & $\mathrm{~N} 2$ & & 0.1106 & -0.0461 & 0.1198 & 337.3657 & 5.8881 \\
\hline 4 & $\mathrm{~K} 2$ & & 0.3435 & 0.1487 & 0.3743 & 156.5922 & 2.7330 \\
\hline 5 & $\mathrm{Kl}$ & & 0.3067 & -0.1480 & 0.3405 & 334.2410 & 5.8336 \\
\hline 6 & 01 & & 0.2159 & -0.1374 & 0.2559 & 212.4729 & 3.70 \\
\hline 7 & P1 & & 0.1251 & 0.0990 & 0.1596 & 141.6322 & 2.4719 \\
\hline 8 & M4 & & 0.0087 & 0.0098 & 0.0131 & 48.3498 & 0.8439 \\
\hline 9 & MS4 & & 0.0050 & -0.0091 & 0.0104 & 299.0703 & 5.2198 \\
\hline & & Devis & & & 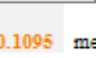 & & \\
\hline
\end{tabular}

Tabel 2. menjelaskan tentang komponen harmonik pasang surut yang dialami periran pelabuhan. Berdasarkan hasil perhitungan bilangan Formzahl diketahui nilai besaran bilangan Formzahl adalah 1,35 Sehingga tipe pasut pada Perairan sekitaran pelabuhan adalah tipe campuran condong ganda (Mixed mainly diurnal tides) artinya bahwaa perairan Punggur Batam mengalami dua kali pasang dalam satu hari dengan perbedaan tinggi dan interval yang berbeda. Analisis komponen pasut dilakukan untuk mendapatkan nilai dari amplitude dan bead fase dari setiap komponen pasut. Metode yang digunakan adalah Least Square. Setelah dilakukan analisis maka diperlukan nilai konstanta harmonik yang di sajikan pada Tabel 3. berikut:

Tabel 3. Hasil peritungan dengan metode Least Square

\begin{tabular}{|c|c|c|}
\hline \multicolumn{3}{|c|}{ HASIL PERHITUNGAN KONSTANTA HARMONIK PASANG SURUT } \\
\hline KONSTANTA & RADIAN/JAM & NILAI FORMZAL \\
\hline K1 & 5,8836 & \multirow{2}{*}{1,352205} \\
O1 & 3,7084 & \\
\cline { 1 - 2 } M2 & 0,8215 & \\
\cline { 1 - 2 } S2 & 6,2721 & \\
\hline
\end{tabular}

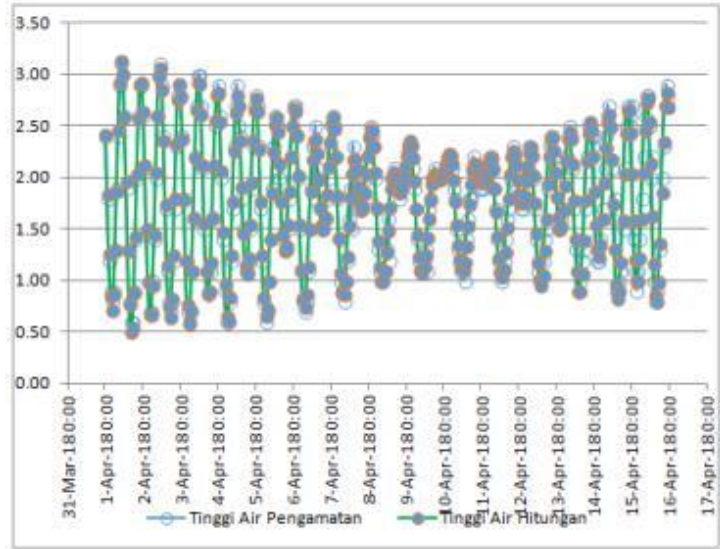

Gambar 4. Hasil grafik dengan metode least square.

Gambar pada 4. menampilkan grafik tipe pasang surut, Hasil siklus 24 jam terjadi dua kali air pasang dan dua kali air surut,dengan demikian,tipe pasang surut pada lokasi penelitian yaitu (Mixed mainly diurnal tides) pasang surut campuran condong ke harian ganda pengolahan data pasut. Pengolahan hasil pengamatan pasang surut menggunakan metode least square menghasilkan komponen harmonik pasang surut Tabel 4.1. Dari nilai-nilai komponen pasang surut didapatkan nilai tinggi muka air rata-rata (Mean Sea Level) sebesar 1,80 meter, muka air tertinggi (High Water Spring/Level) sebesar 3,20 meter dan muka air terendah (Lowes Low Water Spring/Level) sebesar 0.50 meter.

\subsection{Batimetri IDW (Inverse Distance Weighted)}

Hasil pengukuran batimetri yang telah di koreksi dengan nilai MSL 1,35 meter yang menghasilkan akurasi pada nilai kedalaman, Hasil perumunan yang di lakukan memiliki luasan 500 meter, Pengambilan data tidak di lakukan di pinggir pantai(dekat garis pantai,di karenakan multibeam echosounder tidak di anjurkan untur melakukan perumunan pada kedalaman perairan $\leq$.Hasil nilai kedalaman tersebut di interpolasi dengan metode IDW (Inverse Distance Weighted), IDW adalah salah satu teknik interpolasi permukaan dengan prinsip titik inputnya dapat berupa titik pusat, plot yang tersebar secara acak maupun tersebar merata, IDW memperkirakan nilai-nilai 
atribut pada titik-titik yang tidak disampel menggunakan kombinasi linier dari nilai-nilai sampel tersebut dan ditimbang oleh fungsi terbalik dari jarak antar titik (Ihsanul, 2016) Metode IDW menggunakan perangkat lunak Arcgis. nilai-nilai yang di hasil kan pada garis kontur merupakan nilai kedalaman perairan punggur dalam satuan meter dibawah permukaan laut. Hasil penelitian menunjukan nilai kedalaman di perairan punggur berkisar antara 16 - 25 meter di bawah permukaan laut. Hasil rentan kedalaman tersebut sudah terkoreksi oleh pasang surut. Hal ini jelas menunjukan bahwa nilai kedalaman bervariasi, tetapi bentuk dasar perairan tidak terlalu curam.Multibeam mempuyai kemampuan yang sangan representatif untuk sebagai nilai kadalaman yang akurat di peraian pungur gambar pada 4 dan 5 .

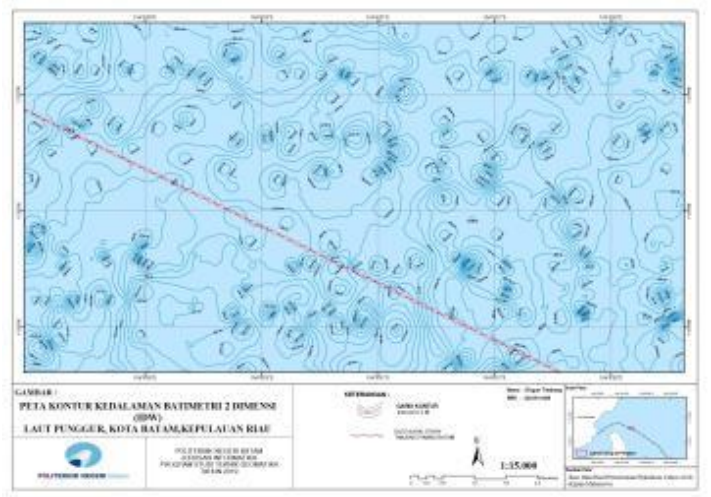

Gambar 5. Hasil peta kontur 2 dimensi (IDW) kedalaman di perairan Punggur, Batam, Kepulauan Riau.

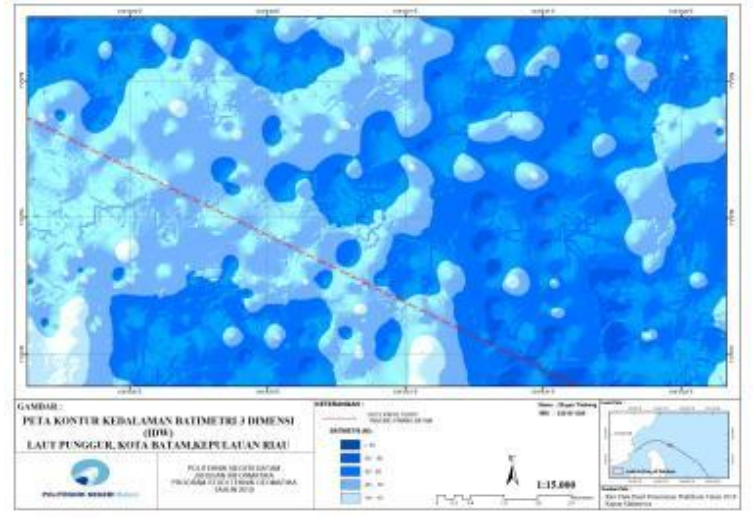

Gambar 6. Hasil peta kontur 3 dimensi (IDW)

kedalaman di perairan Punggur, Batam, Kepulauan

Riau.

Gambar di atas menunjukan range dari warna biru langit menunjukan range kedalaman antara 15-18 biru muda biru muda 18-20 biru 20-22 biru tua 22-25. Pada gambar hasil pengolahan menggunakan Archscene menghasilkan gambar yang memiliki perbedaan warna yang sangat kontras terlihatg pada gambar diatas. Hal ini menunjukkan bahwa perbedaan setiap nilai kedalaman di perairan punggur sangat bervariasi. Hal ini menunjukkan dengan adanya perubahan nilai kedalaman di perairan punggur, Batam, sehingga nilai kedalaman atau batimetri di perairan tersebut tidak termasuk berada di daerah continental shelf yang menjelaskan dengan adanya nilai topografi landau yang berbatasan langsung dengan pesisir pantai[2]. Nilai kedalaman ini dihasilkan dengan nilai pasang tertinggi yaitu 3,2 meter, dan surut terandah yaitu 0,50 meter. Nilai kedalaman akan mengalami perubahan kedalaman (batimetri) di sebuah perairan dari waktu ke waktu yang linear mengikuti dengan nilai tinggi muka air laut yang didapatkan dari hasil pengukuran pasang surut laut, [5] hasil penelitian tersebut mengatakan bahwa daerah landai mempunyai jarak antar kontur yang jarang, sedangkan jarak antar kontur yang dekat/rapat dengan garis kontur lainnya menunjukan daerah tersebut memiliki kedalaman curam, sehingga dapat dikatakan perairan punggur merupakan perairan yang memiliki nilai kedalaman yang landai atau tidak curam.

\subsection{Batimetri Metode Krigging (3D model)}

Hasil krigging yang dilakukan pada nilai kedalaman atau batimetri diperairan punggur, Kepri dilakukan dengan melakukan pengolahan data menggunakan perangkat lunak Surfer. Hasil ini di lakukan dengan nilai median yaitu 104.08792 (x), $1.02548(\mathrm{y})$, dan $-19.74(\mathrm{z})$, midrange yaitu 104.08681 (x), 1.025725 (y), dan -15.15 (z). Hasil dari pengolahan data menggunakan metode krigging dapat dilihat pada gambar 7. dibawah ini: 

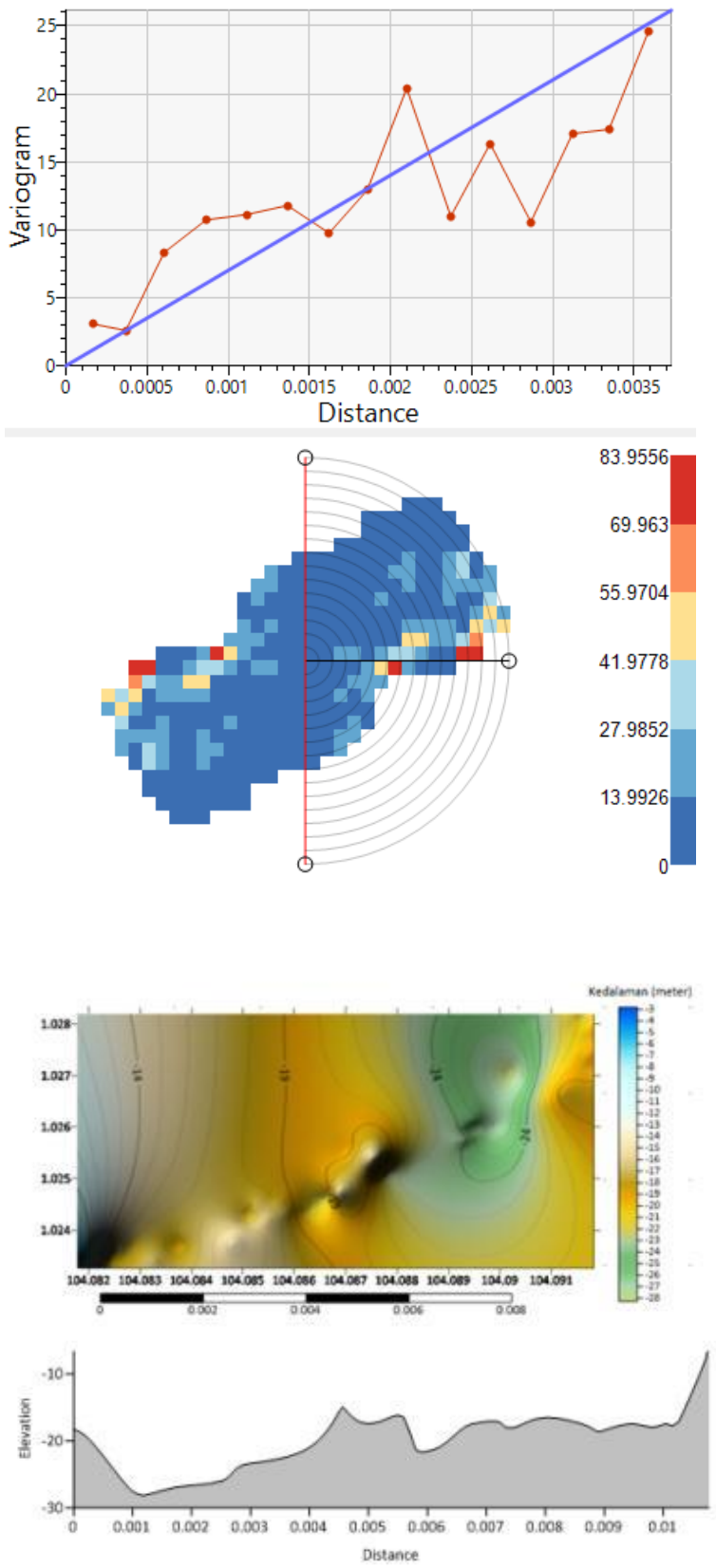

Gambar 7. Penampang melintang dasar Laut di perairan Punggur, Batam, Kepulauan Riau.

Dasar dari penarikan garis pada penampang adalah berfungsi dalam melakukan analisis morfologi dasar perairan pada perairan punggur. Pemilihan dalam menentukan letak garis penampang pada hasil pemetaan 3D batimetri, adalah dari interpretasi yang diestimasikan telah mewakili morfologi dasar perairan di perairan punggur. Hasil pengolahan data untuk penampang melintang pada nilai dasar laut tersebut disajikan dalam Gambar diatas. Hasil dari pengolahan nilai batimetri yang dilakukan dengan menggunakan metode krigging pada gambar peta 3D batimetri diatas menunjukkan bahwa perairan di Punggur, Batam dikatakan landau, dengan nilai batimetri yang bervariasi tetapi tidak meiliki selisih nilai kedalaman yang begitu besar. Penampang melintang morfologi dasar laut digunakan untuk membantu dalam menganalisis bentuk morfologi dasar laut di perairan punggur, Batam, Kepri. Hasil dari pengolahan data yang disajikan pada gambar profil melintang pada morfologi data batimetri perairan punggur menunjukan adanya perbedaan nilai dari kelerengan dasar perairan (Ihsanul, 2016). Hasil Model 3D morfologi dasar perairan memperlihatkan hasil, bahwa permukaan dasar perairan tidak rata, terdapat perbedaan nilai kedalaman yaitu berupan cekungan ataupun permukaan dasar perairan yang lebih tinggi.

\section{Kesimpulan}

Penelitian yang dilakukan di perairan Punggur, Batam menggunakan instrumen multibeam echosounder (MBES) system yang menunjukkan hasil nilai kedalaman perairan (batimetri) memiliki variasi yang berbeda dengan ditunjukkan hasil perbedaan kontur kedalaman yang didapatkan pada hasil penelitian. Hasil penelitian ini sudah melakukan koreksi nilai kedalaman dengan menggunakan chart datum yaitu Mean Sea Level (MSL) dengan nilai 1,35 meter. Tipe pasang surut yang didapatkan dalam penelitian ini adalah tipe pasut pada Perairan sekitaran pelabuhan adalah tipe campuran condong ganda (Mixed mainly diurnal tides). Nilai kontur kedalaman yang dihasilkan dalam penelitian menunjukkan jarang garis kontur yang tidak dekat, hal ini dilakukan dengan menggunakan interpolasi nilai kedalaman setelah koreksi menggunakan IDW. Perairan punggur dapat dikategorikan dengan perairan yang memiliki nilai kedalaman yang tidak curam atau landau

\section{Acknowledgment}

Ucapan terima kasih kepada seluruh pihak yang 
terlibat pada penelitian ini, khususnya kepada responden dan rekan-rekan dosen dan mahasiswa atas kerjasama dan partisipasinya sehingga kegiatan penelitian ini terlaksana dengan baik dan lancer

\section{References}

[1].Denafiar, F. S. (2017). "Pembuatan Program Penentuan Konstanta Harmonik dan Prediksi Data Pasang Surut dengan Menggunakan Visual Basic For Application (Vba) Ms. Excel". Jurnal Geodesi Undip, Jurnal Geodesi Undip , 6(4), 295-304.

[2]. Hutabarat S, E. S. (2008). "Pengantar Oseanografi".Jakarta: UI Press.

[3]. Mahatmawati, A. D. (2009): 31-39. "Perbandingan Fluktuasi Muka Air Laut Rerata (MLR) di Perairan Pantai Utara Jawa Timur dengan Perairan Pantai Selatan Jawa Timur." . Jurnal Kelautan: Indonesian Jousrnal of Marine Science and Technology 2.1, 31-39.

[4]. Masrukhin, M. A. (2014). "Studi batimetri dan morfologi dasar laut dalam penentuan jalur peletakan pipa bawah laut (Perairan Larangan-Maribaya", Kabupaten Tegal). Journal of Oceanography, 3(1), , 94-104.

[5]. Noor, D. (2012.). "Pengantar Geologi".Program Studi Teknik Geologi, Fakultas TeknikUniversitasPakuan, Bogor.

[6]. Ongkosongo, O. S. (1989). "Pasang Surut" Pusat Penelitian dan Pengembangan Oseanologi (P3O LIPI Jakarta.

[7]. Triatmodjo, B. (1999). "Teknik pantai. Beta Offset", Yogyakarta, 397. Bandung.

[8]. Ihsanul, f. (2016). "Perbandingan metode interpolasi IDW, Krigging, dan Spline pada data spasial suhu permukaan laut" Bogor. 